\title{
Seasonal Variations in Soil and Bacteriological Properties as Affected by Phytogenic Mounds (Nebkhas) of Halocnemum strobilaceum in Lake Manzala, Egypt
}

\author{
Heba K. Issa ${ }^{1}$, Magdy I. El-Bana ${ }^{1 \#}$, Magdy M. Bahgat ${ }^{1,2}$ and Mohamed I. Abou \\ Dobara $^{3}$ \\ ${ }^{1}$ Department of Botany, Faculty of Science, Port Said University, Port Said, Egypt; \\ ${ }^{2}$ College of Pharmacy, Jazan University, Saudi Arabia and ${ }^{3}$ Department of Botany\& \\ Microbiology, Faculty of Science, Damietta University, Damietta, Egypt.
}

\begin{abstract}
DHYTOGENIC mounds (nebkhas) formed by halophytes are widely distributed in coastal and desert environments. Such nebkhas provide loci for geochemical and biological activities that influence ecosystem processes and function. Seasonal variation in soil and bacterial properties were investigated within the nebkhas under the canopy of Halocnemum strobilaceum and in the surrounding unvegetated sites at salt marshes of Lake Manzala. The parameters measured include soil moisture, organic matter, total nitrogen and phosphorus, $\mathrm{pH}$, electrical conductivity (EC), and bacterial community and enzyme characteristics. Enrichment ratios for soil salinity and nutrients were evaluated to indicate the salinity and fertility islands within nebkhas. Soil moisture content showed significant differences between the different seasons with the highest value in winter (16.55\%) at unvegetated control site.Soil electrical conductivity, total nitrogen and phosphorus had their significantly higher values in nebkhas during autumn. The enrichment values for the measured soil parameters ranged from 0.31 to 4.09 in the four seasons which indicates a clear accumulation effect for soil nutrients and salts within the nebkhas under the canopy of $H$. strobilaceum. Bacterial abundance was consistently higher in nebkhas through all seasons. Eleven genera of bacteria belong to Firmicutes, Actinobacteria and proteobacteria phyla were recorded in nebkha and unvegetated sites. These genera varied in their occurrence between the two locations and the four seasons. It can be concluded that the formation of nebkhas by halophytic vegetation have noticeable effects on accumulation of soil salinity and fertility during different seasons that affect bacterial abundance and activity in coastal environment.
\end{abstract}

Keywords: Halocnemum strobilaceum, Nebkha, Amylase, Carboxymethylcellulase, Bacteria.

\section{Introduction}

Halophytes are promising plant resources in aridand coastal zones because they can tolerate high saline conditions. Such salt-adapted plant resources are commonly found along coastal plains(Glenn et al., 1991). In arid and semi-arid ecosystems, halophytic communities have many influences on the physical and chemical properties of rhizosphere soil, litter decomposition, and the carbon-nitrogen cycle (Han et al., 2007 and Yan et al., 2010).
Soil microorganisms are important members of terrestrial ecosystems. Microorganisms are sensitive to external environmental changes with the ability to change the community structure (White et al., 1979). These microorganisms are responsible for much of soil organic matter turn over and drive soil nutrient cycling in most ecosystems. The relative abundances of microbial community groups (e.g., fungal and bacterial groups) can vary along environmental gradients (Waldrop \& Firestone, 2006). Along with this variation in microbial community composition, microbial function, as measured through nutrient

"Corresponding author,e-mail: mag_bana@yahoo.co.uk

DOI: 10.21608/ejbo.2017.811.1051

C2017 National Information and Documentation Center (NIDOC) 
turnover, changes may also occur on a seasonal basis (DeForest et al., 2009). Previous studies examining relationship between vegetation patchiness and microbial communities were conducted in a forest ecosystem (Pennanen et al., 2001) or volcanic desert ecosystem (Yoshitake et al., 2013). However, studies on examining the bacterial communities and activity associated with patchiness of halophytic vegetation in an extreme saline-alkali wet land are rare.

In Egypt, the halophytic vegetation is existing in two types of salt marshes namely coastal along the Red Sea and Mediterranean Sea, and inland in the oases and inland desert (Zahran, 1982; El-Khouly \& Zahran, 2002 and El-Bana, 2006). The perennial halophytic shrub Halocnemum strobilaceum (Pall.) Bieb. is among the dominant arido-active species in the salt marshes of Egypt including Lake Manzala (Zahran \& Willis, 2009 and El-Bana, 2015). H. strobilaceum is an obligate halophyte that accumulate wind- or water-borne sediments within and/or around its canopy forming phytogenic mounds (Nebkhas). Nebkhas improve soil properties, microclimate and biodiversity by capturing and preserving soil moisture, nutrients and propagules (Jackson \& Caldwell, 1993; Hesp \& McLachlan, 2000; Dougill \& Thomas, 2002 and El-Bana et al., 2002b; 2003; 2007).
In the current study, the impact of nebkhas formed by $H$. strobilaceum on soil moisture, salinity, nutrients, and bacterial abundance and the soil enzyme activities in different seasons were evaluated at the salt marshes of Lake Manzala. Such information will improve our understanding of the role of halophytic communities in capturing resources and affecting microbial activity in harsh arid environments.

\section{Materials and Methods}

\section{Study area}

Study area is located on the eastern side of Lake Manzala, near El Manasra Village, on the road of Damietta- Port Said where three sites were selected for H. strobilaceum (Fig. 1). Lake Manzala represents the largest lake in the Nile Delta with a present area of $700 \mathrm{~km}^{2}$, and average water depthof $1.0 \mathrm{~m}$ (Rasmussen et al., 2009). It is characterized by an arid climate with hot summer and mild winter. North (N), North-West (NW) and South-West (SW) winds together with El-Khamasin are responsible for the formation of sand dunes and other land forms of the area (Zahran \& Willis, 2009). It is separated from the Mediterranean Sea by strip of land that is very narrow in several places and it is connected with the sea through Algamil outlet.

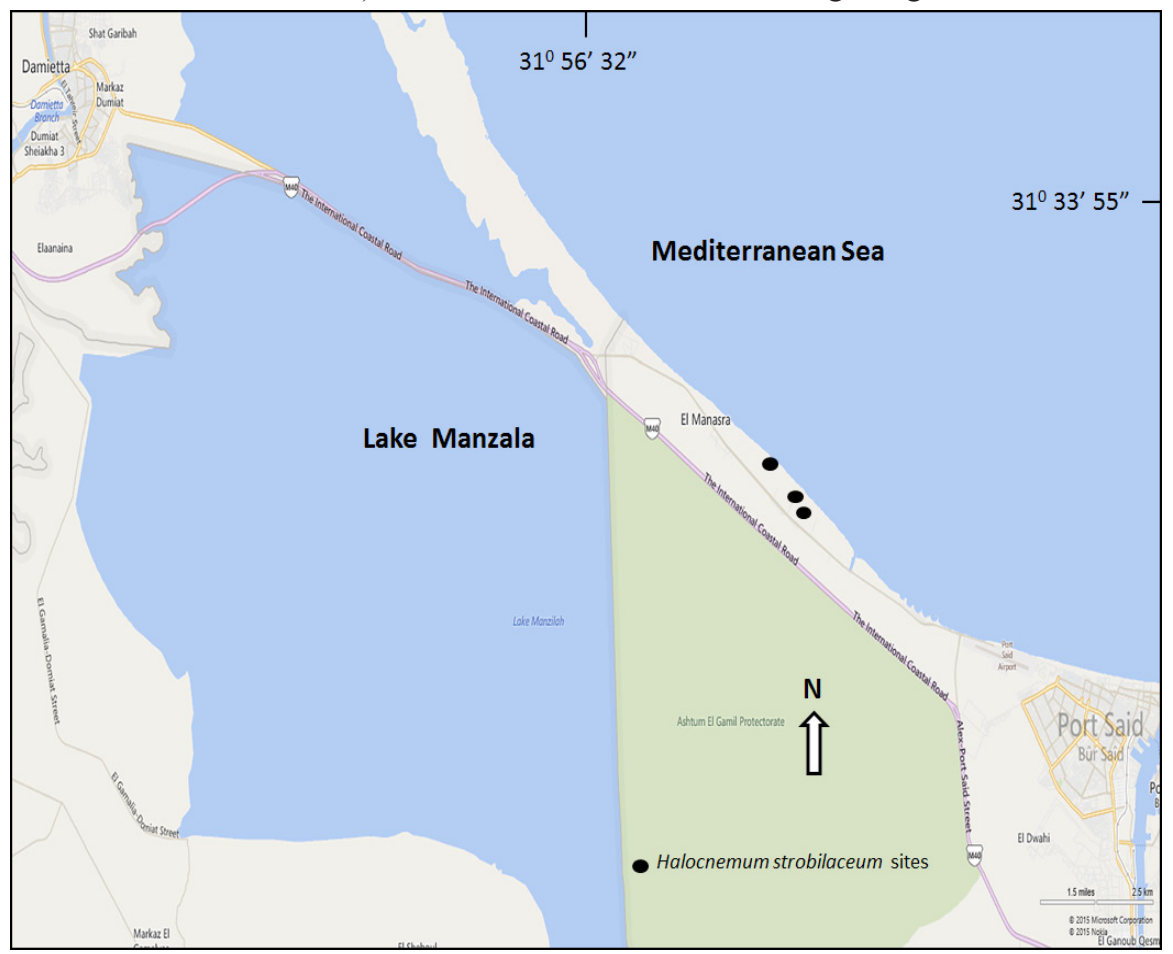

Fig. 1. Location of the study area and sites for sampling Halocnemum strobilaceum nebkhas at the salt marshes of Lake Manzala. (source $($ C) google maps). 
Soil sampling and analysis

Sampling was done seasonally from autumn 2014 to summer 2015. Soil samples were collected from two different locations surrounding three individuals of $H$. strobilaceum: soil within nebkhas beneath the canopy (at about 20-30 $\mathrm{cm}$ distance from the main stem) and from open locations without vegetation (at 150-200 cm outside the canopy) as a control. At each selected plant individual, soil samples were collected from the four cardinal directions to form composite samples by hand auger at 0-20 $\mathrm{cm}$ depth.Soil samples were packed carefully in sterilized polyethylene bags and transported to the laboratory. Each composite soil sample was divided into two parts, one for determination of soil moisture content and bacteriological analysis and the other stored at $4{ }^{\circ} \mathrm{C}$ for chemical analysis.

Soil moisture content has been measured as the ratio of the mass of water present in sample to the mass of the sample after it has been dried at $105^{\circ} \mathrm{C}$ to constant weight (Gardner et al., 2000). Soil organic matter content was determined by the rapid wet oxidation method of Walkley \& Black (1934) protocol as modified and described by Nelson \& Sommers (1996). Total nitrogen was determined using modified Kjeldahl method (Jackson, 1967). Total phosphorus was measured using spectrophotometer according to Black et al. (1965). Soil pH and EC were measured by intelligent $\mathrm{pH}$ meter YK-2001 and Jenway 4510 electrical conductivity meter, respectively, at a soil/water ratio of 1:5.

\section{Isolation and identification of bacteria}

Soil suspension $(0.1 \mathrm{~mL})$ was spread onto Halophilic Nutrient Agar (LMG Medium 220; Atlas, 2010) plates with 3 different salt concentrations: $3 \%, 10 \%$, and $20 \%$ for slight, moderate, extreme halophilic bacteria, respectively according to their salinity requirements, followed by incubation at $30^{\circ} \mathrm{C}$. Isolates were morphologically, physiologically and biochemically identified at genus level according to Bergy's Manual of Systematic Bacteriology edition of vol. 2, 3, 4 and 5 (C) 2005, 2009, 2010 and 2012 respectively). Gram reaction of each isolate was studied. The biochemical tests studied were catalase test, oxidase test (using MICROBACTTM oxidase detection strips), Starch hydrolysis, Cellulolyticactivity (Kasana et al., 2008 and Antony et al., 2009), Acid from glucose fermentation, Growth on MacConkey agar medium. Each isolate was tested for growth at $35^{\circ} \mathrm{C}$ and on Halophilic Nutrient agar medium with $0 \%, 10 \%, 20 \% \mathrm{NaCl}$.

\section{Bacterial abundance}

Total bacterial number was determined by direct counting under epifluorescence microscopy (Olympus BX53 U-RFL-T) according to Hobbie et al. (1977). Calculation of the number of cells per gram of soil was calculated as described by Polyanskaya et al.(2013).

\section{Soil enzymes}

Criteria for choosing enzyme assays were based on their importance in nutrient cycling and organic matter decomposition, and simplicity of the assay (i.e., potential to be adopted by commercial labs for routine soil testing). Amylase and Carboxymethylcellulase (CMCase) activities were detected using UNICO spectrophotometer at $550 \mathrm{~nm}$ according to Ross (1966) and Pancholy \& Rice (1973), respectively.

\section{Statistical analysis}

The obtained data of soil and bacterial properties were subjected to analysis of variance (ANOVA) followed by Scheffe and T-tests to compare means for significance at the $\mathrm{p}<0.05$ level. Correlation coefficients between soil parameters and bacterial characteristics were performed by Pearson correlation coefficients. All statistical analyses were carried out using software SPSS for windows (SPSS Inc., Chicago, IL, USA; Version 16.0).

\section{Results}

\section{Soil variables}

The overall results of ANOVA analysis indicated significant differences in the measured soil properties between the four seasons (F-values, Table 1). Soil moisture recorded significantly its highest value in winter $(16.55 \%)$ at unvegetated site, however it was $14.55 \%$ at the nebkhas under the canopy (Table 1). In summer, the values of moisture content were $5.98 \%$ and $6.05 \%$ in the soil of nebkhas and outside the canopy, respectively. Nebkhas at winter season attained significantly the highest value of organic matter content $(0.84 \%)$ compared to their counterparts in other seasons (Table 1). However, summer season showed the lowest values of organic matter contents with $0.39 \%$ and $0.31 \%$ at nebkha and unvegetated sites, respectively. The total 
nitrogen and phosphorus had their significantly higher values $(1.2 \%$ and $0.43 \%$, respectively) in nebkhas during autumn. Similarly, the highest value of electrical conductivity $(6.27 \mathrm{mS} / \mathrm{cm})$ wasin nebkhas during autumn. Soil $\mathrm{pH}$ ranged between 6.58 and 7.93 at nebkhas in summer and unvegetated sites in autumn.

TABLE 1. Mean values \pm standard error (second line) of soil properties at different seasons and microhabitats in Halocnemum strobilaceum community.

\begin{tabular}{lccccccccc}
\hline Season & \multicolumn{2}{c}{ Autumn } & \multicolumn{2}{c}{ Winter } & \multicolumn{2}{c}{ Spring } & \multicolumn{2}{c}{ Summer } & F-value \\
Microhabitat & $\mathbf{N}$ & Unveg. & $\mathbf{N}$ & Unveg. & $\mathbf{N}$ & Unveg. & N & Unveg. & \\
\hline Moisture (\%) & $6.48^{\mathrm{a}}$ & $5.15^{\mathrm{agv}}$ & $14.55^{\mathrm{ab}}$ & $16.55^{\mathrm{gh}}$ & 11.43 & $12.96^{\mathrm{iv}}$ & $5.98^{\mathrm{b}}$ & $6.05^{\mathrm{hi}}$ & \\
& 0.58 & 0.61 & 1.90 & 0.90 & 0.81 & 1.74 & 0.63 & 0.44 & $17.29^{* * *}$ \\
Organic matter & 0.56 & 0.54 & $0.84^{\mathrm{e}}$ & 0.40 & 0.58 & $0.58^{\mathrm{m}}$ & $0.39^{\mathrm{e}}$ & $0.31^{\mathrm{m}}$ & $2.28^{*}$ \\
$(\%)$ & 0.07 & 0.04 & 0.08 & 0.05 & 0.06 & 0.04 & 0.04 & 0.08 & \\
Total nitrogen & 1.20 & $0.84^{\mathrm{j}}$ & 0.92 & $0.83^{\mathrm{k}}$ & 0.45 & $0.11^{\mathrm{jkl}}$ & 0.65 & $0.84^{1}$ & $5.12^{*}$ \\
$(\%)$ & 0.08 & 0.17 & 0.08 & 0.01 & 0.34 & 0.00 & 0.06 & 0.11 & \\
Total phosphorus & $0.43^{\mathrm{cdq}}$ & $0.21^{\mathrm{c}}$ & $0.25^{\mathrm{cr}}$ & 0.26 & $0.08^{\mathrm{dr}}$ & 0.26 & $0.21^{\mathrm{q}}$ & 0.22 & $5.21^{*}$ \\
$(\%)$ & 0.03 & 0.04 & 0.00 & 0.07 & 0.01 & 0.07 & 0.02 & 0.00 & \\
pH & $7.71^{\mathrm{f}}$ & $7.93^{\mathrm{no}}$ & 7.17 & $6.78^{\mathrm{n}}$ & 7.33 & 7.40 & $6.58^{\mathrm{f}}$ & $6.97^{\circ}$ & $11.31^{* * *}$ \\
& 0.09 & 0.02 & 0.24 & 0.18 & 0.05 & 0.08 & 0.20 & 0.08 & \\
EC (mS/cm) & 6.27 & 5.12 & 4.47 & $5.56^{\mathrm{p}}$ & 2.72 & $2.84^{\mathrm{p}}$ & $3.42^{\mathrm{s}}$ & $4.26^{\mathrm{S}}$ & $6.21^{* * *}$ \\
& 0.95 & 0.73 & 0.71 & 0.13 & 0.22 & 0.35 & 0.02 & 0.03 &
\end{tabular}

-Mean values with the same letters are significantly different at p-level $<0.05$ according to Scheffe's test. F-values with *** and * are significantly different at $\mathrm{p}<0.001$ and $<0.05$, respectively.

-Abbreviations for microhabitats: N, nebkha; Unveg., unvegetated site.

Enrichment ratios for soil variables in the four seasons

The enrichment ratios for soil variables differed significantly between the four seasons (Table 2). The enrichment values for the measured soil variables ranged from 0.31 to 4.09 in the four seasons indicating a clear accumulation effect for soil nutrients and salts in the nebkhas under the canopy of $H$. strobilaceum. There were significant differences in enrichment values for soil moisture content, total phosphorus and soil salinity (EC) between the four seasons, with the highest values being found in the autumn.

TABLE 2. Enrichment ratios (E) of soil variables at the four seasons.

\begin{tabular}{|c|c|c|c|c|c|c|}
\hline \multirow{2}{*}{ Soil variable } & \multicolumn{4}{|c|}{ Season } & \multirow{2}{*}{ F-value } & \multirow{2}{*}{$P$-level } \\
\hline & Autumn & Winter & Spring & Summer & & \\
\hline \multirow[t]{2}{*}{ Soil moisture } & 1.26 & 0.88 & 0.58 & 0.99 & \multirow{2}{*}{11.42} & \multirow{2}{*}{0.001} \\
\hline & 0.95 & 0.12 & 0.47 & 0.42 & & \\
\hline \multirow[t]{2}{*}{ Organic matter } & 1.04 & 2.10 & 1.40 & 1.26 & \multirow{2}{*}{14.13} & \multirow{2}{*}{0.001} \\
\hline & 0.75 & 0.60 & 0.20 & 0.32 & & \\
\hline \multirow[t]{2}{*}{ Total nitrogen } & 1.43 & 1.11 & 4.09 & 0.77 & \multirow{2}{*}{7.31} & \multirow{2}{*}{$<0.001$} \\
\hline & 0.47 & 0.80 & 1.40 & 0.25 & & \\
\hline \multirow[t]{2}{*}{ Total phosphorus } & 2.05 & 0.96 & 0.31 & 0.95 & \multirow{2}{*}{4.65} & \multirow{2}{*}{$<0.001$} \\
\hline & 0.75 & 0.21 & 0.04 & 0.04 & & \\
\hline \multirow[t]{2}{*}{$\mathrm{pH}$} & 0.97 & 1.06 & 0.99 & 0.94 & \multirow{2}{*}{0.85} & \multirow{2}{*}{0.078} \\
\hline & 0.50 & 0.33 & 0.43 & 0.50 & & \\
\hline \multirow[t]{2}{*}{$\mathrm{EC}(\mathrm{mS} / \mathrm{cm})$} & 1.22 & 0.80 & 0.96 & 0.80 & \multirow{2}{*}{1.34} & \multirow{2}{*}{0.004} \\
\hline & 0.32 & 0.46 & 0.31 & 0.67 & & \\
\hline
\end{tabular}

Values are presented as mean \pm standard error (second line). 


\section{Soil bacterial characteristics}

Overall, 11 genera were identified at the nebkha and unvegetated sites, with three phyla (Firmicutes, Actinobacteria and proteobacteria). Firmicutes phylum is presented by six genera including Bacillus, Trichococcus, Listeria, Exiguobacterium, Lactobacillus and Planomicrobium. Actinobacteria phylum includes four genera Arthrobacter, Cellulomonas, Microbacterium and Corynebacterium. However, the genus Salinivibrio belongs to proteobacteria phylum. The tested characteristics of these genera are presented in Table 3. Bacillus, Arthrobacter, Cellulomonas and Listeria were common at both locations (nebkhas and unvegetated sites), however Microbacterium, Corynebacterium, Lactobacillus, Exiguobacterium and Planomicrobium were recorded only in nebkhas. These genera showed seasonal variation in their occurrence (Table 3). For example, Bacillus was recorded in all seasons; but Arthrobacter and Listeria were observed in winter and spring. Furthermore, Microbacterium and Exiguobacterium were recorded only in summer season. Similarly, Corynebacterium and Planomicrobium were collected only in winter season. Trichococcus spp.' colonies are circular, off-white, flat, concentric, entire, translucent. Gram positive, motile and produced acid from glucose fermentation but didn't produce catalase and oxidase. Starch and cellulose were not hydrolyzed. Its growth on medium with $0 \%$ concentration of $\mathrm{NaCl}$ was occurred but not at $10 \%$ and $20 \%$. This genus grew at unvegetated sites during autumn. Genus Salinivibrio was morphologically characterized with oval, white, flat, smooth, entire, opaque colony. Gram negative, motile, catalase, oxidase and acid from glucose fermentation were recorded. Its growth with pink colonies was observed on MacConker agar medium as well as on media with 0,10 and $20 \%$ of $\mathrm{NaCl}$.

Bacterial total abundance per $\mathrm{g}$ fresh soil showed significant seasonal and spatial variations (Fig. 2). In all seasons, nebkhas had higher total bacterial counts compared to unvegetated sites. The highest total count $\left(1.22 \times 10^{9}\right.$ cells $\left./ \mathrm{g}\right)$ was recorded in soil of nebkhas during summer season. A paired T-test showed that there were significant differences $(p<0.05)$ in the total bacterial abundance between the two sampling locations (nebkhas and unvegetated sites) in all four seasons (Fig. 2). Bacterial abundance was significantly negative correlated with soil organic matter content (Table 4).
Soil enzyme activities

Amylase enzyme had its lowest activity in winter which had the highest activity of carboxymethylcellulase enzyme (Fig. 3a, b). For amylase, nebkhas recorded significantly higher activities in autumn and summer, while it had lower activities in winter and spring (Fig. 3a). Carboxymethylcellulase activity of nebkhas was lower than unvegetated sites only in summer season only (Fig. 3b). Amylase enzyme was negatively correlated with soil moisture content at a significant level $(\mathrm{P}<0.01)$. However, Carboxymethylcellulase enzyme activity showed a significant positive correlation with organic matter (Table 4).

\section{Discussion}

Vegetation types generally alter soil properties by nutrient cycling and litter decomposition. Consequently, the community of soil microorganisms can also be affected by variations in plant community root exudates (Sarig \& Steinberger, 1994 and Zahran, 1997). In the current research, the nebkhas of the halophytic species $H$. strobilaceum showed variations in soil variables as well as in bacterial abundance and activity compared with surrounding unvegetated sites. Moisture content of soil is crucial for both plants and microorganisms that rely heavily on water in soils and water is essential for nutrient cycle (Yan et al., 2015). It has been documented that soil moisture content vary in both time and space, and consequently affect microbial activity and growth (Kieft et al., 1987). The moisture content in the soil of unvegetated sites was higher compared to that of nebkhas of $H$. strobilaceum. This could be related to the presence of extensive root system of this species that deplete moisture content by evapotranspiration within nebkhas (Batanouny \& Batanouny, 1968 and Batanouny, 2001 ), and could be also due to the interception of rain fall by the canopy (Kröpfl et al., 2002). Considering temporal variation in soil moisture content, the highest values of moisture content for soil in the nebkhas were in winter while the lowest values were in summer. These results are in accordance with the seasonal patterns of precipitation along the Mediterranean Coast of Egypt, with rainfall concentrated in winter while summer is always rainless and with high temperature and evapotranspiration (Zahran \& Willis, 2009). 


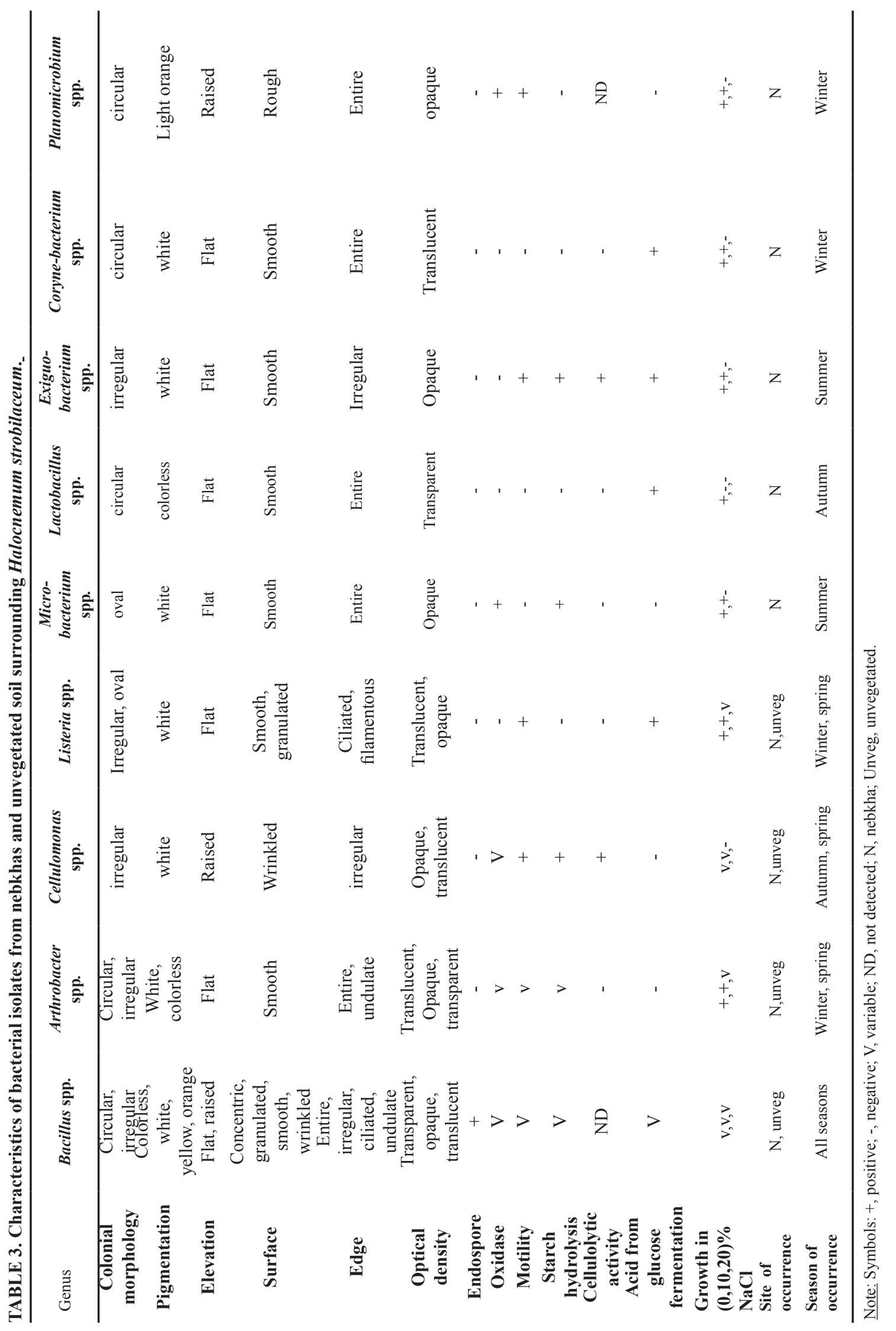

Egypt. J. Bot. (2017) 


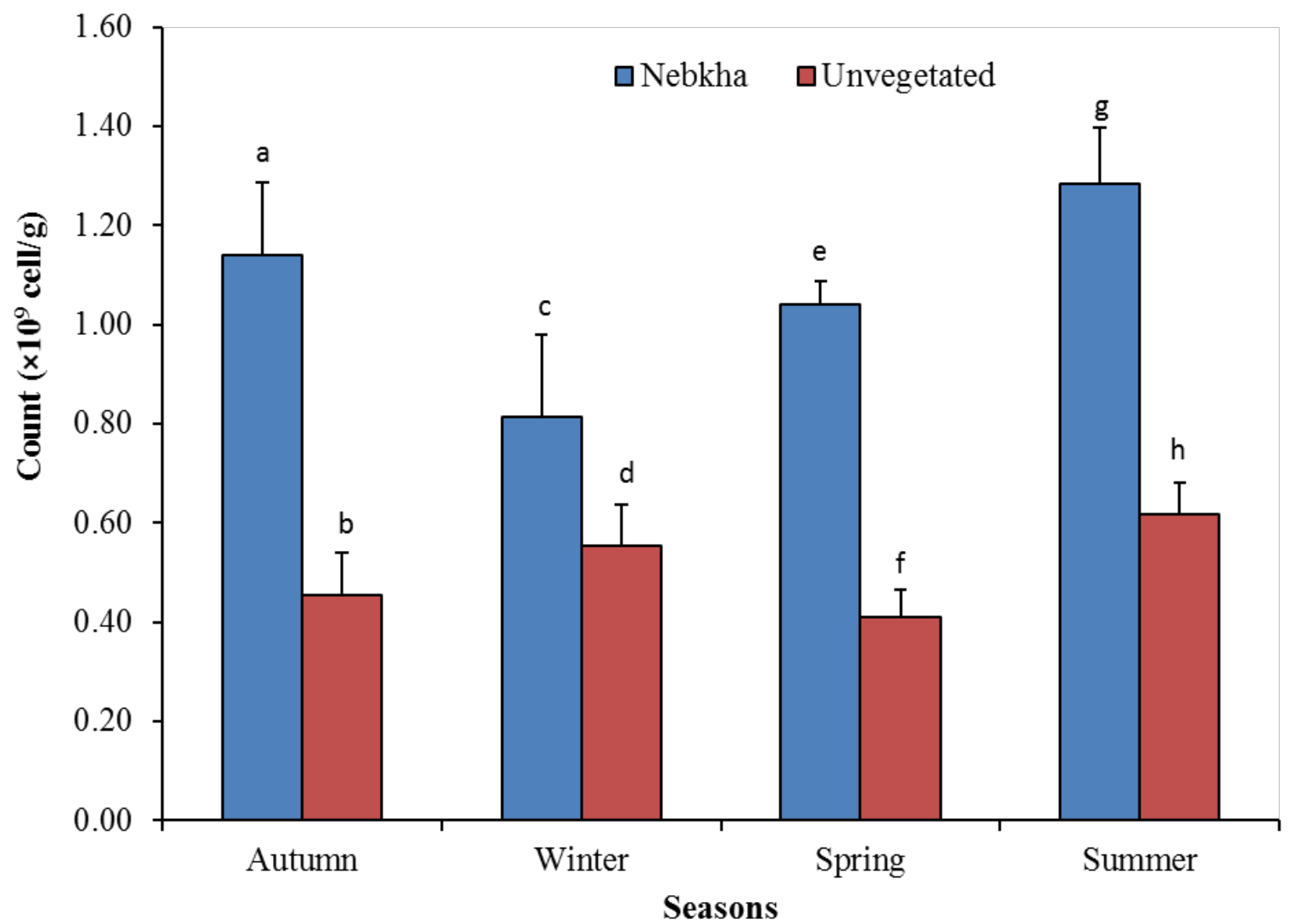

Fig. 2. Seasonal variations in total bacterial counts of soil collected from nebkhas of Halocnemum strobilaceum and unvegetated sites. Bars with lowercase letters represent significant difference $(P<0.05)$ between the two sampling locations (nebkha and unvegetated sites).

TABLE 4. Pearson correlations coefficients of soil parameters with bacterial abundance and measured enzyme activities.

\begin{tabular}{lccc}
\hline Soil parameter & $\begin{array}{c}\text { Bacterial } \\
\text { abundance }\end{array}$ & Amylase activity & CMCase activity \\
\hline Soil moisture & -0.42 & $-0.91^{* *}$ & 0.49 \\
Total nitrogen & $-0.57^{*}$ & 0.34 & -0.38 \\
Total phosphorus & -0.34 & $0.59^{*}$ & -0.16 \\
Organic matter & $-0.62^{* *}$ & -0.45 & $0.63^{* *}$ \\
pH & -0.32 & -0.16 & 0.09 \\
EC & -0.50 & 0.39 & -0.04 \\
\hline
\end{tabular}

**: Correlation is significant at the 0.01 level; *: Correlation is significant at the 0.05 level (2-tailed). 
(a)

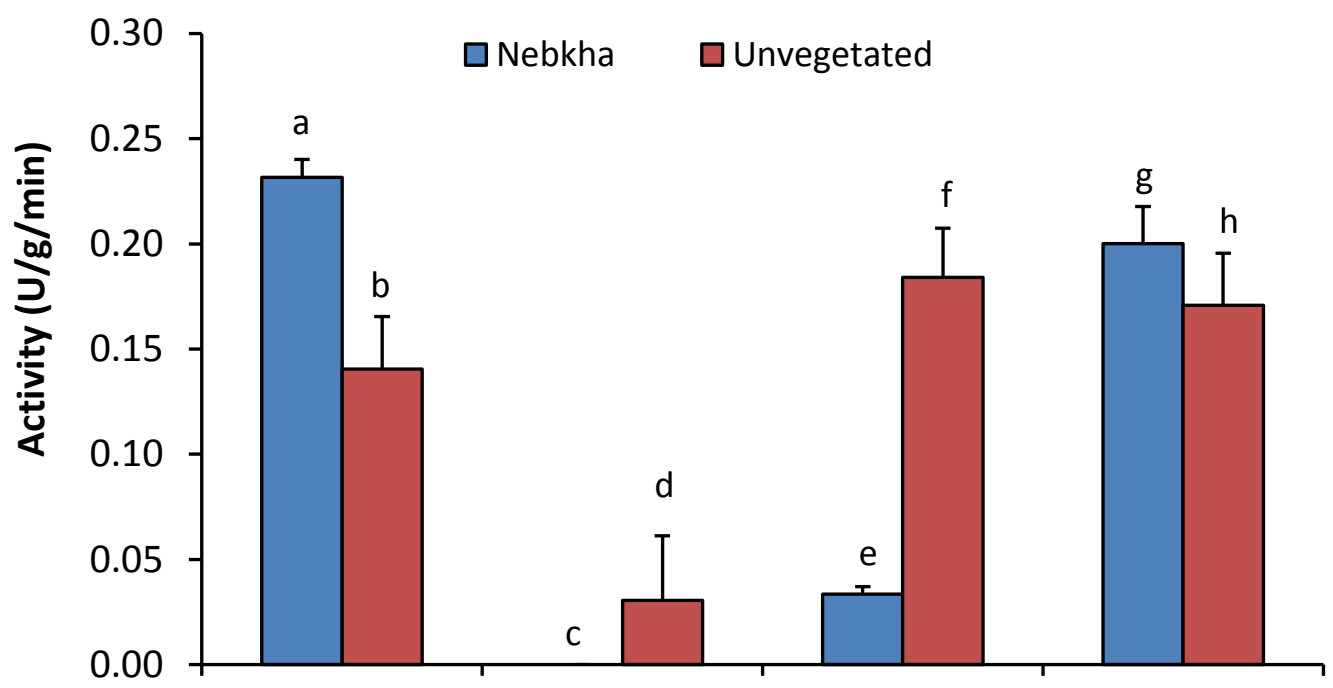

(b)

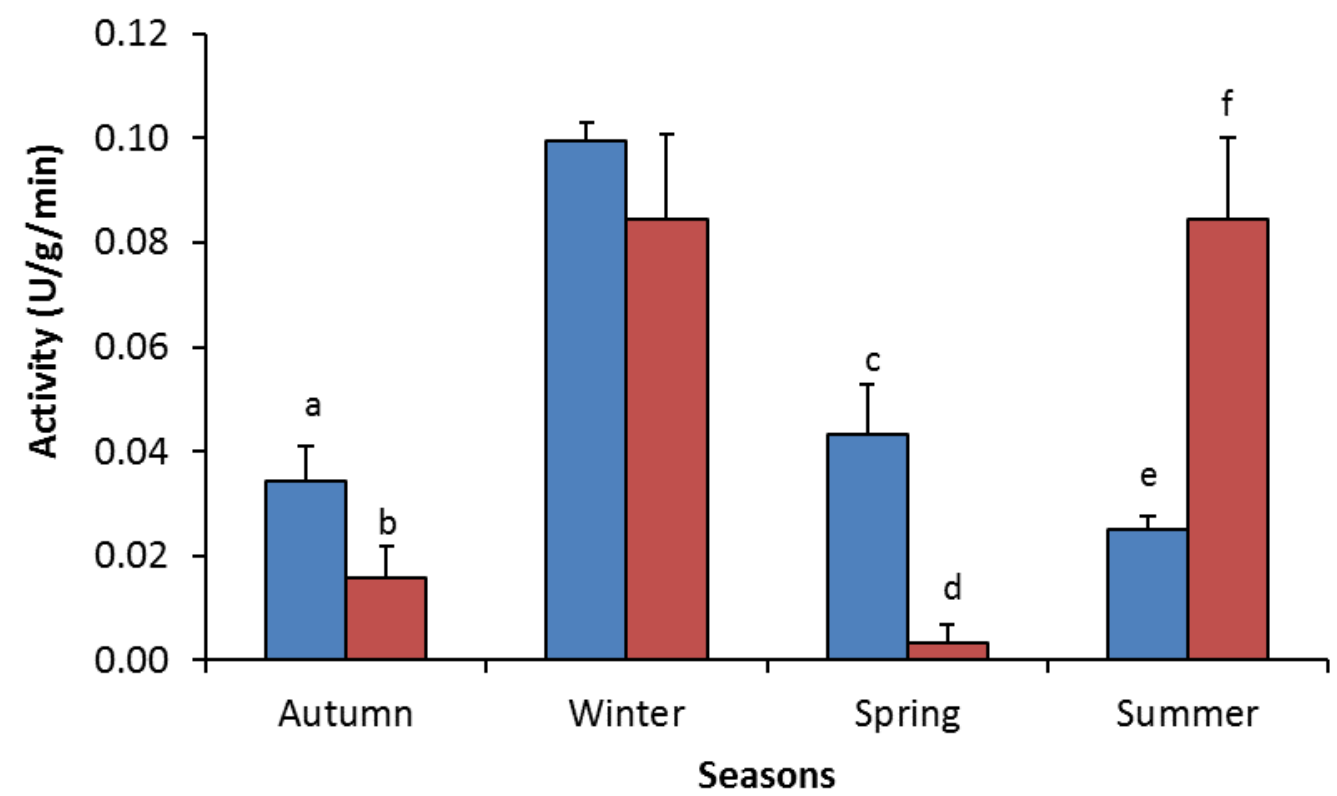

Fig. 3. Seasonal variations in amylase (a) and CMCase (b) enzyme activities of soil collected from nebkhas of Halocnemum strobilaceum and unvegetated sites. Bars with lower case letters represent significant difference $(\mathrm{P}<0.05)$ between the two sampling locations (nebkha and unvegetated sites). 
Generally, soil salinity as indicated by EC- was higher in unvegetated sites compared to nebkhas in all seasons except in autumn. This could be attributed to the high accumulation of salts within the vegetative parts of $H$. strobilaceum (Zahran, 1989 and Zahran \& Willis, 2009) that fall on the soil of nebkhas leading salts accumulation under the canopy and increasing soil salinity during autumn (Sarig \& Steinberger, 1994). Salinization can be restricted by leaching of salt from root zone so that higher salinities were in unvegetated soil as reported by Shrivastava \& Kumar (2014). The lowest salinities were recorded during the growing season in spring. This could be related to the growing season at which $H$. strobilaceum absorb large amounts of salts from the soil, lowering the soil salinity (Zahran \& Willis, 2009).

Results reported higher organic matter and total nitrogen contents in the soil of nebkhas of H. strobilaceum compared with their unvegetated surrounding soils. Similar findings were also reported by El-Bana et al. (2002a, 2003), Li et al. (2007) and Pool et al. (2013). Such enrichment of these contents in soil of nebkhas could be related to the litter accumulation and decomposition of host plants forming nebkhas and its associated species as well as trapping of materials during wind storms (El-Bana et al., 2003). Li et al. (2007) attributed the differences in total nitrogen and phosphorus due to prolonged microorganism activity that enabled expanded organic matter decomposition.

Soil $\mathrm{pH}$ showed differences between nebkha and vegetated sites as well as between different seasons. Such variations could be attributed to nature of organic matter, soil moisture content and decomposition rates of foliage of shrub and annual species in the different locations and seasons (Marcar et al., 1999). For example, the breakdown of accumulated litter and higher microbial activity in the nebkhas under the canopy, may lead to a decrease in soil pH (Ladenburger et al., 2006).

Niemi et al. (2005) suggested that the soil enzyme activities vary seasonally, which depends on the chemical, physical, and biological characteristics of the soil. In the current study, CMCase enzyme was more active in winter. Previous studies have suggested that the peak of soil enzyme activity does not always appear in the season of higher temperature (Sinsabaugh et al., 1993; Harris \& Safford, 1996; Burger \& Kelting,
1999 and Criquet et al., 2000). Button (1991) found that bulk (unvegetated) soil is dominated by oligotrophic microorganisms with higher catalytic efficiency as well as rate of dispersion of enzyme-substrate complexes. This finding is supporting higher activities of enzymes noticed in the unvegetated soil.

Amylase enzyme was negatively correlated with moisture as reported by Zaveri et al. (2016). This could be due to the compact of soil by soil moisture. Studies had shown that the compact soil had significantly lower biomass C (38\% decrease) and lower enzyme activities (decrease in range from $41-75 \%$ ) than the uncompacted soil (Orchard \& Cook, 1983 and Dick et al., 1988). The organic matter and organic carbon content of soil are accelerated by cellulase, which degrades cellulose in plant debris to glucose, cellobiose and high-molecular-mass oligosaccharides (White, 1982). Thus, CMCase enzyme activity showed a significant positive correlation with organic matter. It was obvious that total bacterial counts were significantly higher in nebkha than unvegetated sites. This might be due to the nature of root exudates (Zahran, 1997).

Significant negative correlation was found between organic matter and bacterial abundance. Visser et al. (1983) reported that bacteria were enhanced more than fungi and actinomycetes under low nutrient regimes and other environmental stresses in disturbed soils in Alberta, Canada. Yuan et al. (2007) suggested that low soil organic matter and high salinity in soils may produce an unsuitable substrate for the development of fungi and actinomycetes in the microbial biomass. In contrast, high soil organic matter and low salinity in soils may favor fungal dominance in microbial biomass as indicated by high microbial biomass $\mathrm{C}$ to biomass $\mathrm{N}$ ratio. Bacterial dominance may also inhibit the decomposition of complex organic material in saline soils (Badran, 1994), because fungi are especially important for the breakdown of lignin and cellulose in decaying plant residues (Harper \& Lynch, 1985).

Gram-negative bacterial isolates were less than Gram-positive bacteria as the later can better tolerate high matric potential than Gramnegative bacteria because they have stronger cell walls (Martin et al., 1999; Fierer et al., 2003; Schimel et al., 2007 and Vasileiadis et al., 2012). Our results revealed obvious difference 
of bacterial composition in different microhabitat of $H$. strobilaceum. Bacterial composition clearly displayed seasonal and spatial varitions. More genera were discovered in winter than any other seasons, and some special genera appeared only in specific season. Specific genera were only detected at nebkha and this result is compatible with a study done on rhizosphere of Salicornia sp showing that the composition of microbial communities was influenced more by root activity than by soil composition (Mapelli et al., 2013).

It can be concluded that the formation of nebkhas by halophytic vegetation have noticeable effects on accumulation of soil salinity and fertility during different seasons that affect bacterial abundance and activity in coastal environment.

\section{References}

Antony, R., Krishnan, K., Thomas, S., Abraham, W. P. and Thamban, M. (2009) Phenotypic and molecular identification of Cellulosimicrobium cellulans isolated from Antarctic snow. Antonie. Van. Leeuwenhoek, 96, 627-634.

Atlas, R.M. (2010) "Handbook of Microbiological Media", CRC press.

Badran, R. (1994) Cellulolytic activity of some cellulose-decomposing fungi in salinized soils. Acta Mycologica, 29, 245-251.

Batanouny, K. (2001) "Plants in the Deserts of the Middle East".(Adaptations of desert organisms). Berlin, etc.: Springer-Verlag.

Batanouny, K. and Batanouny, M. (1968) Formation of phytogenic hillocks. II. Rooting habitat of plants forming phytogenic hillocks. Acta Bot. Acad. Sci. Hungaricae, 14, 1-18.

Black, C., Evans, D., White, J., Ensminger, L. and Clark, F. (1965) "Method of Soil Analysis". Part II. Am. Soc. Agron, Madison, USA. p. 1572.

Burger, J. A., and Kelting, D.L. (1999) Using soil quality indicators to assess forest stand management. Forest Ecology and Management, 122, 155-166.

Button, D. (1991) Biochemical basis for whole-cell uptake kinetics: specific affinity, oligotrophic capacity, and the meaning of the Michaelis constant. Applied and Environmental Microbiology, 57, 2033-2038.
Criquet, S., Farnet, A., Tagger, S. and Le Petit, J. (2000) Annual variations of phenoloxidase activities in an evergreen oak litter: influence of certain biotic and abiotic factors. Soil Biology and Biochemistry, 32,1505-1513.

DeForest, J. L., Chen, J. and McNulty, S. G. (2009) Leaf litter is an important mediator of soil respiration in an oak-dominated forest. International Journal of Biometeorology, 53, 127-134.

Dick, R., Myrold, D. and Kerle, E. (1988) Microbial biomass and soil enzyme activities in compacted and rehabilitated skid trail soils. Soil Science Society of American Journal, 52, 512-516.

Dougill, A. J. and Thomas, A. D. (2002) Nebkha dunes in the Molopo Basin, South Africa and Botswana: formation controls and their validity as indicators of soil degradation. Journal of Arid Environments, 50, 413-428.

El-Bana, M. I. (2006) Floristic composition of a threatened Mediterranean sabkhat of Sinai.In: "Sabkha Ecosystems II" Khan, M.A.; Böer, B.; Kust, G.S.; Barth, H. \& (Ed.), pp.109-122. Springer Publishers.

El-Bana, M. I. (2015) Gravel pads of powerl ine towers as human-made habitats for ruderal vegetation in some Mediterranean wetlands of Egypt: Implications for management. The Egyptian Journal of Aquatic Research, 41, 83-91.

El-Bana, M., Khedr, A. H., Van Hecke, P. and Bogaert, J. (2002a) Vegetation composition of a threatened hypersaline lake (Lake Bardawil), North Sinai. Plant Ecology, 163, 63-75.

El-Bana, M. I., Nijs, I. and Kockelbergh, F. (2002b) Microenvironmental and vegetational heterogeneity induced by phytogenic nebkhas in an arid coastal ecosystem. Plant and Soil, 247, 283-293.

El-Bana, M. I., Nijs, I. and Khedr, A. H. A. (2003) The importance of phytogenic mounds (Nebkhas) for restoration of arid degraded rangelands in Northern Sinai. Restoration Ecology, 11, 317-324.

El-Bana, M. I., Li, Z. Q. and Nijs, I. (2007) Role of host identity in effects of phytogenic mounds on plant assemblages and species richness on coastal arid dunes. Journal of Vegetation Science, 18, 635-644. 
El-Khouly, A. and Zahran, M. (2002) On the Ecology of the Halophytic Vegetation of the Oases in Egypt, pp. 277-286. In, Proceedings of the International Symposium on the optimum resources utilization in salt-affected ecosystems in arid and semi-arid regions.

Fierer, N., Schimel, J. and Holden, P. (2003) Influence of drying-rewetting frequency on soil bacterial community structure. Microbial Ecology, 45, 63-71.

Gardner, C. M., Robinson, D., Blyth, K. and Cooper, J.D. (2000) Soil water content. "Soil analysis: Physical Methods" pp. 1-74.

Glenn, E.P., O'Leary, J.W., Watson, M.C., Thompson, T. L. and Kuehl, R. O. (1991) Salicornia bigelovii Torr.: an oil seed halophyte for seawater irrigation. Science, 251, 1065-1067.

Han, X.M., Wang, R.Q., Jian, L., Wang, M.C., Juan, Z. and Guo, W.H. (2007) Effects of vegetation type on soil microbial community structure and catabolic diversity assessed by polyphasic methods in North China. Journal of Environmental Sciences, 19, $1228-1234$.

Harper, S. and Lynch, J. (1985) Colonization and decomposition of straw by fungi. Transactions of the British Mycological Society, 85, 655-661.

Harris, M. and Safford, L. (1996) Effects of season and four tree specieson soluble carbon content in fresh and decomposing litter of temperateforests1. Soil Science, 161, 130-135.

Hesp, P. and McLachlan, A. (2000) Morphology, dynamics, ecology and fauna of Arctotheca populifolia and Gazania rigens nabkha dunes. Journal of Arid Environments, 44, 155-172.

Hobbie, J.E., Daley, R.J. and Jasper, S. (1977) Use of nuclepore filters for counting bacteria by fluorescence microscopy. Applied and Environmental Microbiology, 33, 1225-1228.

Jackson, M. L. (1967) "Soil Chemical Analysis". New Delhi: Prentice Hall of India.

Jackson, R. and Caldwell, M. (1993) Geostatistical patterns of soil heterogeneity around individual perennial plants. Journal of Ecology, 81, 683-692.

Kasana, R. C., Salwan, R., Dhar, H., Dutt, S. and Gulati,
A. (2008) A rapid and easy method for the detection of microbial cellulases on agar plates using Gram's iodine. Current Microbiology, 57, 503-507.

Kieft, T. L., Soroker, E. and Firestone, M. K. (1987) Microbial biomass response to a rapid increase in water potential when dry soil is wetted. Soil Biology and Biochemistry, 19, 119-126.

Kröpfl, A. I., Cecchi, G.A., Villasuso, N.M. and Distel, R.A. (2002) The influence of Larrea divaricata on soil moisture and on water status and growth of Stipa tenuis in southern Argentina. Journal of Arid Environments, 52, 29-35.

Ladenburger, C.G., Hild, A.L., Kazmer, D.J. and Munn, L.C. (2006) Soil salinity patterns in Tamarix invasions in the Bighorn Basin, Wyoming, USA. Journal of Arid Environments, 65, 111-128

Li, J., Zhao, C., Zhu, H., Li, Y. and Wang, F. (2007) Effect of plant species on shrub fertile island at an oasis-desert ecotone in the South Junggar Basin, China. Journal of Arid Environments, 71, 350-361.

Mapelli, F., Marasco, R., Rolli, E., Barbato, M., Cherif, H., Guesmi, A., Ouzari, I., Daffonchio, D. and Borin, S. (2013) Potential for plant growth promotion of rhizobacteria associated with Salicornia growing in Tunisian hypersaline soils. BioMed Research International. http://dx.doi. org $/ 10.1155 / 2013 / 248078$

Marcar, N., Ismail, S., Hossain, A. and Ahmad, R. (1999) Trees, shrubs and grasses for saltlands: an annotated bibliography, Australian Centre for International Agricultural Research Canberra.

Martin, D.D., Ciulla, R.A. and Roberts, M.F. (1999) Osmoadaptation in archaea. Applied and Environmental Microbiology, 65, 1815-1825.

Nelson, D. W. and Sommers, L.E. (1996) Total carbon, organic carbon, and organic matter. "Methods of Soil Analysis". Part 3, pp. 961-1010.

Niemi, R., Vepsäläinen, M., Wallenius, K., Simpanen, S., Alakukku, L. and Pietola, L. (2005) Temporal and soil depth-related variation in soil enzyme activities and in root growth of red clover (Trifolium pratense) and timothy (Phleum pratense) in the field. Applied Soil Ecology, 30, 113-125.

Orchard, V.A. and Cook, F. (1983) Relationship 
between soil respiration and soil moisture. Soil Biology and Biochemistry, 15, 447-453.

Pancholy, S. K. and Rice, E. L. (1973) Soil enzymes in relation to old field succession: amylase, cellulase, invertase, dehydrogenase, and urease. Soil Science Society of American Journal, 37, 47-50.

Pennanen, T., Strömmer, R., Markkola, A. and Fritze, H. (2001) Microbial and plant community structure across a primary succession gradient. Scandinavian Journal of Forest Research, 16, 37-43.

Polyanskaya, L., Gorodnichev, R. and Zvyagintsev, D. (2013) Sizes of bacterial cells in soils determined by cascade filtration technique. Biology Bulletin, 40,130-137.

Pool, M. R., Pool, S. K., Parvaneh, I., Dehghani, Z. and Rostamian, M. (2013) Nebkhas of Salvadora persica and their effect on the growth and survival of Prosopis cineraria, Tamarix aphylla and Capparis decidua trees and shrubs. Flora-Morphology, Distribution, Functional Ecology of Plants, 208, 502-507.

Rasmussen, E. K., Svenstrup Petersen, O., Thompson, J., Flower, R. and Ahmed, M. (2009) Hydrodynamicecological model analyses of the water quality of Lake Manzala (Nile Delta, Northern Egypt). Hydrobiologia, 622, 195-220.

Ross, D. (1966) A survey of activities of enzymes hydrolysing sucrose and starch in soils under pasture. Journal of Soil Science, 17, 1-15.

Sarig, S. and Steinberger, Y. (1994) Microbial biomass response to seasonal fluctuation in soil salinity under the canopy of desert halophytes. Soil Biology and Biochemistry, 26, 1405-1408.

Schimel, J., Balser, T. C. and Wallenstein, M. (2007) Microbial stress-response physiology and its implications for ecosystem function. Ecology, 88,1386-1394.

Shrivastava, P. and Kumar, R. (2014) Soil salinity: A serious environmental issue and plant growth promoting bacteria as one of the tools for its alleviation. Saudi Journal of Biological Sciences, 22, 123-131.

Sinsabaugh, R.L., Antibus, R., Linkins, A., McClaugherty, C., Rayburn, L., Repert, D. and Weiland, T. (1993) Wood decomposition: nitrogen and phosphorus dynamics in relation to extracellular enzyme activity. Ecology, 74, 1586-1593.

Vasileiadis, S., Coppolecchia, D., Puglisi, E., Balloi, A., Mapelli, F., Hamon, R. E., Daffonchio, D. and Trevisan, M. (2012) Response of ammonia oxidizing bacteria and archaea to acute zinc stress and different moisture regimes in soil. Microbial Ecology, 64, 1028-1037.

Visser, S., Griffiths, C. L. and Parkinson, D. (1983) Effects of surface mining on the microbiology of a prairie site in Alberta, Canada. Canadian Journal of Soil Science, 63, 177-189.

Waldrop, M. and Firestone, M. (2006) Seasonal dynamics of microbial community composition and function in oak canopy and open grassland soils. Microbial Ecology, 52, 470-479.

Walkley, A. and Black, I. A. (1934) An examination of the Degtjareff method for determining soil organic matter, and a proposed modification of the chromic acid titration method. Soil Science, 37, 29-38.

White, A.R. (1982) Visualization of cellulases and cellulose degradation, pp. 489-509, "Cellulose and Other Natural Polymer Systems". Springer.

White, D., Davis, W., Nickels, J., King, J. and Bobbie, R. (1979) Determination of the sedimentary microbial biomass by extractible lipid phosphate. Oecologia, 40, 51-62.

Yan, H., Gu, X. and Shen, H. (2010) Microbial decomposition of forest litter: a review. Chinese Journal of Ecology, 29, 1827-1835.

Yan, N., Marschner, P., Cao, W., Zuo, C. and Qin, W. (2015) Influence of salinity and water content on soil microorganisms. International Soil and Water Conservation Research, 3, 316-323.

Yoshitake, S., Fujiyoshi, M., Watanabe, K., Masuzawa, T., Nakatsubo, T. and Koizumi, H. (2013) Successional changes in the soil microbial community along a vegetation development sequence in a subalpine volcanic desert on Mount Fuji, Japan. Plant and Soil, 364, 261-272.

Yuan, B. C., Li, Z. Z., Liu, H., Gao, M. and Zhang, Y. Y. (2007) Microbial biomass and activity in salt affected soils under arid conditions. Applied Soil Ecology, 35, 319-328. 
Zahran, H. (1997) Diversity, adaptation and activity of the bacterial flora in saline environments. Biology and Fertility of Soils, 25, 211-223.

Zahran, M.A. (1982) "Ecology of the halophytic vegetation of Egypt", pp. 3-20, Contributions to the Ecology of Halophytes. Springer.

Zahran, M.A. (1989) "Principles of Plant Ecology and Flora of Egypt". Dar El-Nashr for Egyptian Universities. El-Wafa Library, Cairo, Egypt.
Zahran, M. A. and Willis, A. J. (2009) "The vegetation of Egypt", Vol. 2, Springer Science \& Business Media.

Zaveri, P., Patel, R., Rana, P., Shah, B., Mahto, N. and Munshi, N. S. (2016) Assessment of Enzyme Activity and functional microbial diversity in coastal and desert soil ecosystems of Gujarat. Journal of Enzymology and Metabolism, 2, 107.

\section{التفيرات الموسمية في خصائص التربة والبكتريا المصاحبة لنباك نبات الحطب الحدادي Halocnemum strobilaceum

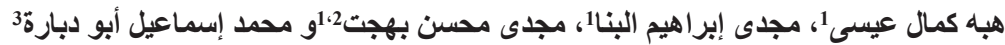

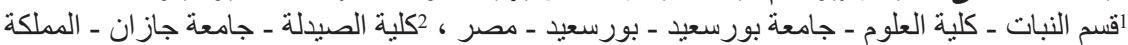

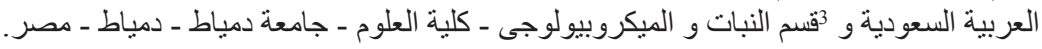

\footnotetext{
تتميز النباتات الملحية بقدرتها على تجميع الرواسب المحمولة من قبل الرياح أو الماء في ظلالها وتكوين

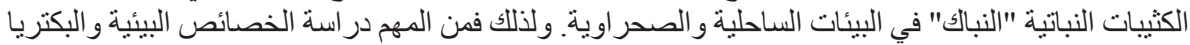

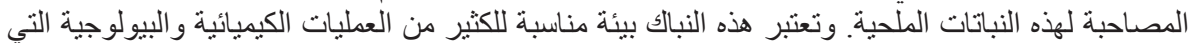

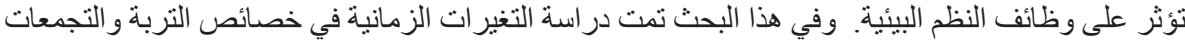
البكتيرية لمنطقة نباك الحطب الحدادي والمناطق الخالية من الغطاء النباتى في المستنقعات المئية الملحية لبحيرة

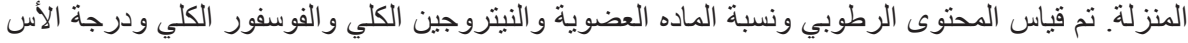

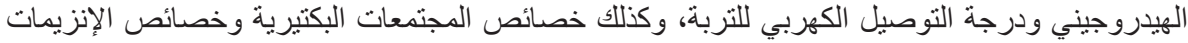

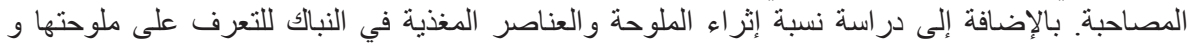

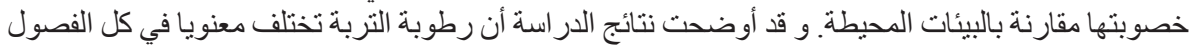

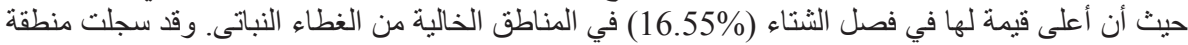

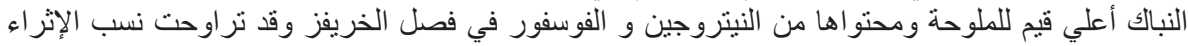

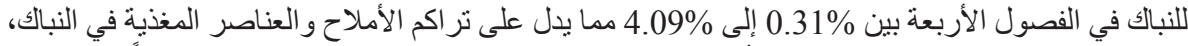

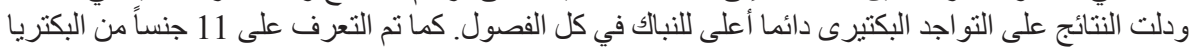

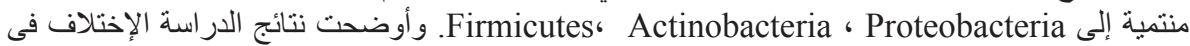

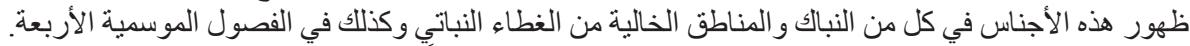

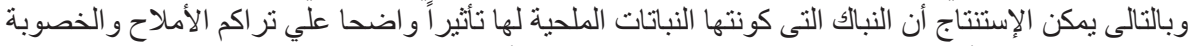
في خلال الفصول الأربعة التي بدور ها تؤثر على وفرة وتنوع و أنشطة المجتمعات البكتيرية في البيئات الساحلية.
} 